\title{
PENINGKATAN UNSUR HARA KALIUM DALAM TANAH MELALUI APLIKASI POC BATANG PISANG DAN SABUT KELAPA
}

\author{
Increasing Potassium on Soil with Application of Banana Stem Liquid Fertilizer and Coconut \\ Liquid Fertilizer
}

\author{
${ }^{1 *}$ Sitti Rahma, ${ }^{1}$ Burhanuddin Rasyid, ${ }^{1}$ Muh.Jayadi \\ ${ }^{1}$ Departemen Ilmu Tanah, Fakultas Pertanian, Universitas Hasanuddin, Makassar \\ Corresponding email: sittirahma29@yahoo.co.id
}

\section{ABSTRACT}

In Indonesia, there is not much use of potassium fertilizer for plants. Generally, farmers are more familiar with nitrogen and phosphorus fertilizers than potassium. This is caused potassium is expensive and hard to find, so there should be another alternative for easily and economic potassium fertilizer. This study aims to analyze the effect of organic liquid fertilizer produced from banana stem and coconut fiber to increase Potassium in soil and maize growth on excassava cultivation land in Moncongloe Bulu Village, Moncongloe District, Maros Regency. The study used randomized block design within two factors and replied for three times. The first factor is coconut liquid fertilizer with 4 levels; SK1 (50 ml/pot), SK2 (100 ml/pot), SK3 (150 ml/pot) and SK4 (200 $\mathrm{ml} /$ pot). The second factor is banana liquid fertilizer with 4 levels; BP1 (25ml/pot), BP2 (50ml/pot), BP3 (75ml/pot) and BP4 $(100 \mathrm{ml} / \mathrm{pot})$, so there are 27 total of treatment units. The results showed that coconut liquid fertilizer significantly affected plant height, number of leaves, dry matter weight, dry root weight, matter weight, root weight, organic carbon, cation exchanged capacity, percentage Potassium of maize, and gained the highest average of Pottassium increasing in soil. Nevertheless, it has not significant effect to soil $\mathrm{pH}$.

Keywords: coconut liquid fertilizer, banana liquid fertilizer, potassium, maize

\section{PENDAHULUAN}

Di Indonesia, penggunaan pupuk $\mathrm{K}$ untuk tanaman belum banyak dilakukan, karena terbatasnya informasi tentang ketersediaan pupuk K. Umumnya petani lebih mengenal pupuk $\mathrm{N}$ dan $\mathrm{P}$ dibanding $\mathrm{K}$. Hal ini juga disebabkan karena masih sedikit endapan mineral sumber bahan baku pupuk $\mathrm{K}$ di Indonesia yang ekonomis untuk dieksplorasi, bahkan hanya sedikit di Asia (Sheldrick, 1985). Proses pelapukan batuan yang banyak mengandung unsur kalium juga membutuhkan waktu yang lama agar dapat tersedia untuk tanaman (Ahmad, 2011).

Kalium dalam tanah terdapat dalam jumlah yang cukup bervariasi, yaitu antara $0.3-2.5 \%$ (Mutscher, 1995; Havlin et al., 1999). Pada tanah yang banyak mengandung liat mempunyai kadar kalium dapat dipertukarkan yang tinggi yaitu sekitar $4 \%$ dari total $\mathrm{K}$ yang terdapat dalam tanah (Mengel dan Kirkby, 1982).

Secara umum, ubi kayu relatif banyak membutuhkan hara $\mathrm{K}$ jika dibandingan dengan tanaman pangan yang lain (padi, jagung, kedelai, kacang tanah). Oleh karena itu, salah satu penyebab tanah kekurangan unsur hara $\mathrm{K}$ adalah penanaman ubi kayu secara terus menerus sehingga berakibat pada penurunan unsur hara yang cepat terutama unsur $\mathrm{N}$ dan $\mathrm{K}$ (Agbaje, 2004). Kebutuhan tanaman akan hara $K$ sangat banyak bahkan melebihi kebutuhan $\mathrm{N}$.

Berdasarkan defisiensi $\mathrm{K}$ akibat budidaya ubi kayu, kurangnya sumber bahan baku $\mathrm{K}$ di Indonesia, serta besarnya kebutuhan akan unsur hara $\mathrm{K}$ pada tanaman. 
Perlu adanya alternatif untuk menghasilkan $\mathrm{K}$ dengan memanfaatkan sumber limbah dan bahan yang mudah untuk diperoleh. Salah satu alternatif yang dapat dilakukan adalah membuat pupuk yang diperoleh dari sisa tanaman.

Pupuk organik cair merupakkan larutan hasil dari pembusukan bahan-bahan organik yang berasal dari sisa tanaman, kotoran hewan dan manusia yang kandungan unsur haranya lebih dari satu unsur (Lingga dan Marsono, 2003).

Dalam batang pisang terdapat unsurunsur penting yang dibutuhkan tanaman, kandungan unsur hara yang terdapat dalam batang pisang yaitu N, P, dan K (Sugiarti, 2011), oleh karena itu batang pisang dapat dijadikan sebagai bahan pupuk organik cair. Selain batang pisang, satu buah kelapa ratarata dapat diperoleh sebanyak $0,4 \mathrm{~kg}$ serabut. Sabut kelapa mengandung 20\%-30\% kalium (Rahmasari, 2008).

Berdasarkan uraian di atas maka dilakukan penelitian dengan tujuan untuk mengetahui peningkatan unsur hara $\mathrm{K}$ dalam tanah dan pertumbuhan tanaman jagung setelah penambahan POC batang pisang dan POC sabut kelapa.

Kegunaan dari penelitian ini adalah sebagai bahan informasi atau referensi untuk petani ataupun peneliti yang akan melakukan penelitian mengenai peningkatan unsur hara kalium dan pertumbuhan tanaman jagung pada tanah kekurangan kalium.

\section{METODE PENELITIAN}

\section{Lokasi dan waktu}

Penelitian ini dilaksanakan pada bulan Agustus 2018 sampai Januari 2019 di Experimental Farm Fakultas Pertanian, Universitas Hasanuddin. Analisis sampel tanah dilaksanakan di Laboratorium Kimia Kesuburan Tanah, Departemen Ilmu Tanah, Fakultas Pertanian, Universitas Hasanuddin. Lokasi pengambilan sampel tanah bekas ubi kayu berada di Desa Moncongloe Bulu, Kecamatan Moncongloe, Kabupaten Maros, lokasi koordinat pengambilan sampel tanah adalah $119^{\circ} 33^{\prime} 13,95^{\prime}$ 'BT dan 5'8'53,28' LS.

\section{Alat dan Bahan}

Alat yang digunakan dalam penelitian ini adalah pot $10 \mathrm{~kg}$, timbangan analitik, shaker, labu ukur, tabung reaksi, pipet ukur, pipet isi. Bahan yang digunakan dalam penelitian ini adalah sampel tanah, benih jagung Bima-19, air, pupuk sp36, pupuk urea, pupuk organik cair batang pisang dan pupuk organik cair sabut kelapa.

\section{Metode Penelitian}

Metode penelitian menggunakan rancangan acak kelompok dengan 9 perlakuan. Setiap perlakuan diulang sebanyak 3 kali. Berikut merupakan perlakuan yang dicobakan pada tanaman jagung:

1. Kontrol (K0)

2. POC sabut kelapa (50ml/pot) (SK1)

3. POC sabut kelapa (100ml/pot) (SK2)

4. POC sabut kelapa (150ml/pot) (SK3)

5. POC sabut kelapa $(200 \mathrm{ml} / \mathrm{pot})(\mathrm{SK} 4)$

6. POC batang pisang (25/pot) (BP1)

7. POC batang pisang (50/pot) (BP2)

8. POC batang pisang (75/pot) (BP3)

9. POC batang pisang (100/pot) (BP4)

\section{Pelaksanaan Penelitian}

\section{Penyiapan Media Tanam}

Sampel tanah diambil secara komposit pada kedalaman 0 sampai $20 \mathrm{~cm}$, diambil dari 4 titik dari titik sampel searah 4 arah mata angin dengan radius $\pm 10 \mathrm{~m}$, tanah dikering udarakan, selanjutnya dihaluskan lalu diayak dengan ayakan bermata saring $2 \mathrm{~mm}$ untuk media tanam dan $0,5 \mathrm{~mm}$ untuk keperluan analisis awal sampel tanah. Selanjutnya sampel tanah berdiameter $2 \mathrm{~mm}$ dimasukkan ke dalam pot dengan berat $10 \mathrm{~kg} /$ pot dan diberi label.

\section{Persiapan POC}

Menyiapkan dua perlakuan berbeda, yaitu POC batang pisang dan POC sabut kelapa. POC yang digunakan terjamin dan tidak terkontaminasi. Kedua pupuk difermentasi selama 2 minggu sampai pupuk benar-benar matang untuk digunakan. 


\section{Inkubasi}

POC batang pisang dan POC sabut kelapa masing-masing dicampurkan dengan air lalu disiram pada tanah dalam pot hingga kapasitas lapang agar POC yang diaplikasikan mengenai seluruh tanah. Sebelum disiram, tanah diaduk terlebih dahulu kemudian POC disiramkan ke dalam pot secara merata dan didiamkan selama 2 minggu didalam inkubasi.

\section{Penanaman}

Tanah yang telah diinkubasi ditanami benih jagung varietas Bima-19. Benih jagung ditanam sedalam 3-5 cm sebanyak 3 biji per pot. Setelah penanaman, diberikan pupuk dasar dengan takaran SP36 $100 \mathrm{~kg} / \mathrm{ha}$ atau dalam $10 \mathrm{~kg}$ tanah setara dengan $0,50 \mathrm{~g}$. Aplikasi pupuk urea dilakukan pada awal tanam yaitu 7 HST sebanyak $1 \mathrm{~g}$ dan urea $0,5 \mathrm{~g}$ setalah 35 HST. Pupuk diaplikasi dengan cara membenamkan ke dalam tanah dengan jarak $\pm 5 \mathrm{~cm}$ dari benih yang telah ditanam.

\section{Pemupukan}

Pemupukan yang dilakukan setelah 14 HST dengan mengaplikasikan masing-masing perlakuan POC, lalu pemupukan kedua dilakukan pada 28 HST, kemudian pada saat tanaman berusia 35 HST diaplikasikan urea 0,5 g sebagai pupuk dasar, dan pemupukan terakhir dilakukan pada tanaman berusia 42 HST. Secara keseluruhan tanaman dipupuk sebanyak 3 kali setelah 14 HST.

\section{Parameter Pengamatan}

Parameter yang diamati pada penelitian ini antara lain: kalsium dapat dipertukarkan, natrium dapat dipertukarkan, magnesium dapat dipertukarkan, kapasitas tukar kation, $\mathrm{K}$ tersedia, C-organik, $\mathrm{pH}$ tanah, berat segar, berat kering, tinggi tanaman, dan jumlah daun. Pengamatan dan panen dilakukan pada umur tanaman 56 HST.

\section{Analisis Data}

Data hasil pengamatan dianalisis menggunakan analisis sidik ragam (ANOVA), apabila terdapat pengaruh perlakuan yang nyata dilanjutkan dengan uji BNJ taraf $0,05 \%$.

\section{HASIL DAN PEMBAHASAN}

\section{Hasil}

\section{Analisis Sebelum Perlakuan}

Berikut merupakan hasil analisis tanah sebelum diberikan perlakuan untuk seluruh parameter yang digunakan pada penelitian, yaitu:

Tabel 1. Hasil analisis tanah sebelum perlakuan

\begin{tabular}{|c|c|c|}
\hline Sifat Kimia & anah & Nilai \\
\hline $\mathrm{C}$ - Organik & & $1,01 \%$ \\
\hline Kapasitas & Tukar & $16,92 \mathrm{cmol} / \mathrm{kg}$ \\
\hline \multicolumn{3}{|l|}{ Kation } \\
\hline - $\mathrm{Ca}$ & & - $\quad 6,90 \mathrm{cmol} / \mathrm{kg}$ \\
\hline - $\quad \mathrm{Mg}$ & & - $\quad 2,70 \mathrm{cmol} / \mathrm{kg}$ \\
\hline - $\mathrm{Na}$ & & - $\quad 0,13 \mathrm{cmol} / \mathrm{kg}$ \\
\hline $\mathrm{K}$ tersedia & & $0.25 \mathrm{cmol} / \mathrm{kg}$ \\
\hline $\mathrm{pH}$ & & 6,08 \\
\hline Tekstur & & Lempung Berliat \\
\hline
\end{tabular}

Berdasarkan kriteria sifat kimia tanah pusat penelitian tanah (1983), persentase COrganik tanah tergolong rendah, $\mathrm{pH}$ tanah yang tergolong agak masam, adapun kandungan $\mathrm{Ca}$ tanah tergolong sedang, $\mathrm{Mg}$ tergolong tinggi dan $\mathrm{Na}$ tergolong rendah. Sifat kimia lainnya, yaitu KTK tanah tergolong sedang. K-tersedia dianalisis dengan metode penjenuhan menggunakan Ammonium Asetat $\left(\mathrm{NH}_{4} \mathrm{OAc} \mathrm{pH}\right.$ 7), kandungan $\mathrm{K}$ tersedia pada tanah tergolong rendah. Hal ini sesuai dengan pendapat (Agbaje, 2004) bahwa salah satu penyebab defisiensi hara $\mathrm{K}$ dalam tanah adalah penanaman ubi kayu secara terus menerus sehingga berakibat pada penurunan unsur hara yang cepat terutama unsur $\mathrm{N}$ dan $\mathrm{K}$. Adapun sifat fisik tanah yang dianalisis 
adalah tekstur, jenis tekstur tanah termasuk lempung berliat.

Tabel 2. Hasil analisis pupuk organik cair

\begin{tabular}{lc}
\hline \multicolumn{1}{c}{ Analisis Pupuk } & $\mathbf{K}_{2} \mathbf{O}(\boldsymbol{\%})$ \\
\hline Batang Pisang (BP) & 1.21 \\
Sabut Kelapa (SK) & 2.48 \\
\hline
\end{tabular}

Berdasarkan analisis pupuk organik cair diperoleh data bahwa hasil olah limbah batang pisang menjadi pupuk organik cair mengandung $\mathrm{K}_{2} \mathrm{O}$ sebesar $1,21 \%$ dan sabut kelapa sebesar 2,48\%. Hal ini sesuai dengan pendapat (Prawoso, 2001) bahwa sabut kelapa bisa digunakan sebagai bahan untuk pembuatan pupuk organik cair, karena didalam sabut kelapa terdapat unsur hara makro dan mikro. Sementara, menurut Satuhu et al (1999), batang pisang memiliki kandungan bahan mineral kalium disamping serat (selulosa), bahan mineral kalsium, fosfor dan besi.

\section{Tinggi Tanaman}

Rata-rata tinggi tanaman jagung pada umur 56 HST ditunjukkan pada Gambar 1 berikut.

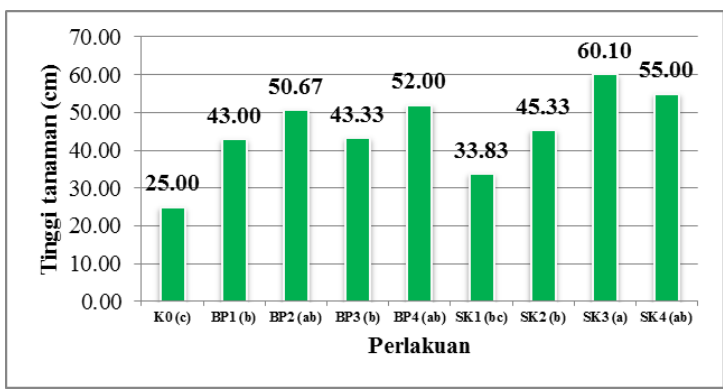

Gambar 1. Grafik rata-rata tinggi tanaman padasetiap perlakuan (perlakuan yang diikuti oleh huruf-huruf yang sama (a,b,c,d,e,f) berarti tidak berbeda nyata pada uji taraf BNJ $0,05 \%$ serta menggunakan nilai pembanding $\mathrm{BNJ} 13,80$ )

Analisis sidik ragam menunjukkan bahwa perlakuan SK3 memberikan pengaruh nyata terhadap tinggi tanaman. Gambar 1 menunjukkan bahwa perlakuan SK3 menunjukkan hasil tanaman tertinggi, yaitu $60,10 \mathrm{~cm}$ dan $\mathrm{K} 0$ menunjukkan hasil tanaman terendah yaitu $25 \mathrm{~cm}$. Berdasarkan uji lanjutan BNJ pada taraf $0,05 \%$ memberikan hasil bahwa perlakuan SK3 berbeda nyata dengan K0, BP1, BP3, SK1 dan SK2 serta tidak berbeda nyata dengan BP2, BP4 dan SK4.

\section{Jumlah Daun}

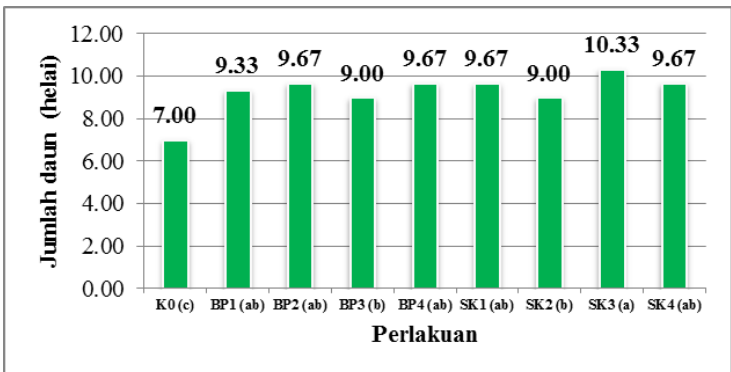

Gambar 2. Grafik rata-rata jumlah daun pada setiap perlakuan (perlakuan yang diikuti oleh huruf-huruf yang sama (a,b,c,d,e,f) berarti tidak berbeda nyata pada uji taraf BNJ $0,05 \%$ serta menggunakan nilai pembanding BNJ 1,12)

Analisis sidik ragam menunjukkan bahwa perlakuan SK3 memberikan pengaruh nyata terhadap jumlah daun. Gambar 2 menunjukkan bahwa perlakuan SK3 menunjukkan hasil nilai rata-rata tertinggi yaitu 10,33 helai dan P0 menunjukkan hasil rata-rata jumlah daun terendah yaitu 7 helai. Berdasarkan uji lanjutan BNJ pada taraf $0,05 \%$ memberikan hasil bahwa perlakuan SK3 berbeda nyata dengan K0, BP3 dan SK2 serta tidak berbeda nyata dengan BP1, BP2, BP4, SK1 dan SK4.

\section{Berat Segar Tanaman}

Analisis sidik ragam menunjukkan bahwa perlakuan SK3 memberikan pengaruh nyata terhadap berat segar tanaman. Gambar 3 menunjukkan bahwa perlakuan SK3 menunjukkan hasil berat segar tanaman nilai rata-rata tertinggi yaitu $199,10 \mathrm{~g}$ dan K0 menunjukkan hasil rata-rata berat segar tanaman terendah yaitu $83,20 \mathrm{~g}$. Berdasarkan uji lanjutan BNJ pada taraf 0,05\% memberikan hasil bahwa perlakuan SK3 berbeda nyata dengan $\mathrm{K} 0$, BP1, BP4 dan 
SK1 serta tidak berbeda nyata dengan BP2, BP3, SK2 dan SK4.

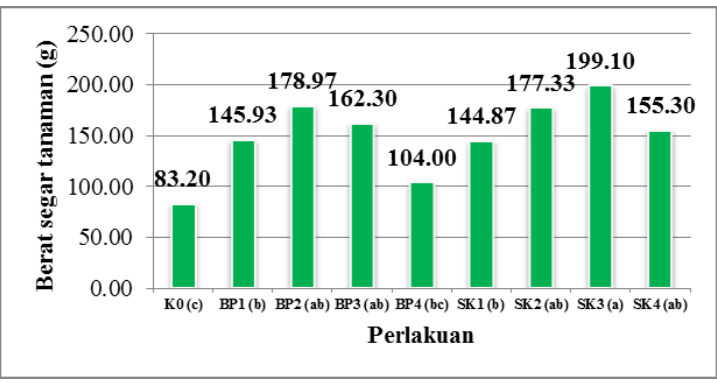

Gambar 3. Grafik rata-rata berat segar tanaman pada setiap perlakuan (perlakuan yang diikuti oleh huruf-huruf yang sama $(\mathrm{a}, \mathrm{b}, \mathrm{c}, \mathrm{d}, \mathrm{e}, \mathrm{f})$ berarti tidak berbeda nyata pada uji taraf BNJ 0,05\% serta menggunakan nilai pembanding BNJ 43,84).

\section{Berat Kering Tanaman}

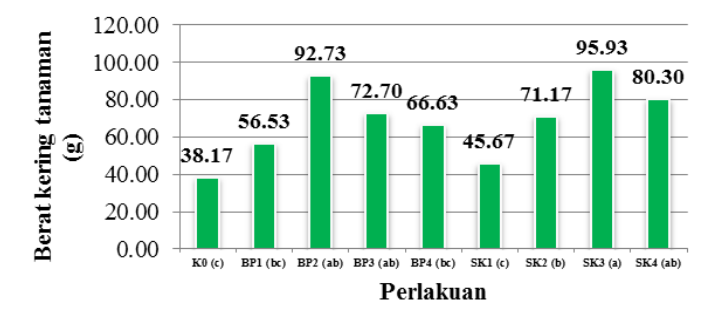

Gambar 4. Grafik rata-rata berat kering tanaman pada setiap perlakuan (perlakuan yang diikuti oleh huruf-huruf yang sama (a,b,c,d,e,f) berarti tidak berbeda nyata pada uji taraf BNJ 0,05\% serta menggunakan nilai pembanding BNJ 24,22 ).

Analisis sidik ragam menunjukkan bahwa perlakuan memberikan pengaruh nyata terhadap berat kering tanaman. Gambar 4 menunjukkan bahwa perlakuan SK3 menunjukkan hasil berat kering tanaman nilai rata-rata tertinggi yaitu 95,93 $\mathrm{g}$ dan $\mathrm{K} 0$ menunjukkan hasil rata-rata berat kering tanaman terendah yaitu 38,17 g. Berdasarkan uji lanjutan BNJ pada taraf $0,05 \%$ memberikan hasil bahwa perlakuan SK3 berbeda nyata dengan K0, BP1, BP4,
SK1 serta SK2 dan tidak berbeda nyata dengan BP2, BP3 dan SK4.

\section{Berat Segar Akar}

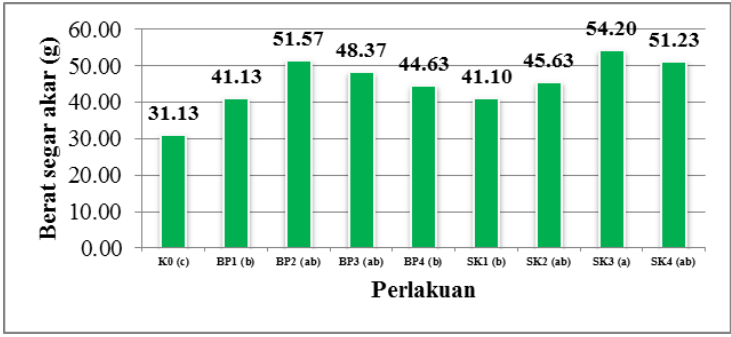

Gambar 5. Grafik rata-rata berat segar akar pada setiap perlakuan (perlakuan yang diikuti oleh huruf-huruf yang sama (a,b,c,d,e,f) berarti tidak berbeda nyata pada uji taraf BNJ $0,05 \%$ serta menggunakan nilai pembanding BNJ 9,24).

Analisis sidik ragam menunjukkan bahwa seluruh perlakuan memberikan pengaruh nyata terhadap berat segar akar. Gambar 5 menunjukkan bahwa perlakuan SK3 menunjukkan hasil berat segar akar nilai rata-rata tertinggi yaitu 54,20 g dan $\mathrm{K} 0$ menunjukkan hasil rata-rata berat segar akar terendah yaitu 31,13 g. Berdasarkan uji lanjutan BNJ pada taraf $0,05 \%$ memberikan hasil bahwa perlakuan SK3 berbeda nyata dengan K0, BP1 dan SK1 serta tidak berbeda nyata dengan BP2, BP3, SK2 dan SK4.

\section{Berat Kering Akar}

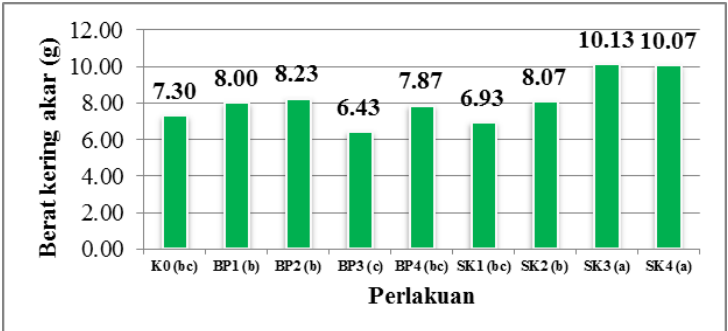

Gambar 6. Grafik rata-rata berat kering akar pada setiap perlakuan (perlakuan yang diikuti oleh huruf-huruf yang sama (a,b,c,d,e,f) berarti tidak berbeda nyata pada uji taraf BNJ 0,05\% serta menggunakan nilai pembanding BNJ 1,45). 
Analisis sidik ragam menunjukkan bahwa seluruh perlakuan memberikan pengaruh nyata terhadap berat kering akar. Gambar 6 menunjukkan bahwa perlakuan SK3 menunjukkan hasil berat kering akar nilai rata-rata tertinggi yaitu $10,13 \mathrm{~g}$ dan $\mathrm{BP} 3$ menunjukkan hasil rata-rata berat kering terendah yaitu 6,43 g. Berdasarkan uji lanjutan BNJ pada taraf 0,05\% memberikan hasil bahwa perlakuan SK3 berbeda nyata dengan K0, BP1, BP2, BP3, BP4, SK1 dan SK2 serta tidak berbeda nyata dengan SK4

\section{C-Organik (\%)}

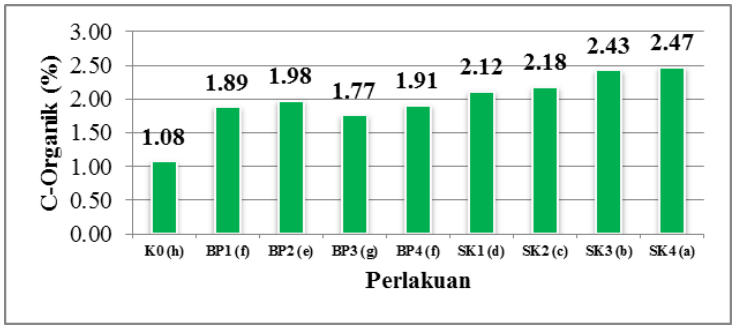

Gambar 7. Grafik rata-rata c-organik tanah pada setiap perlakuan (perlakuan yang diikuti oleh huruf-huruf yang sama (a,b,c,d,e,f) berarti tidak berbeda nyata pada uji taraf BNJ $0,05 \%$ serta menggunakan nilai pembanding $\mathrm{BNJ} 0,04$ ).

Analisis sidik ragam menunjukkan bahwa perlakuan SK4 memberikan pengaruh sangat nyata terhadap c-organik tanah. Gambar 7 menunjukkan bahwa perlakuan SK4 menunjukkan hasil c-organik nilai ratarata tertinggi yaitu $2,47 \%$ dan $\mathrm{K} 0$ menunjukkan hasil rata-rata c-organik tanah terendah yaitu $1,08 \%$. Berdasarkan uji lanjutan BNJ pada taraf $0,05 \%$ memberikan hasil bahwa perlakuan SK4 berbeda nyata dengan semua perlakuan.

\section{pH}

Analisis sidik ragam menunjukkan bahwa perlakuan BP4 memberikan pengaruh sangat nyata terhadap keasaman tanah. Gambar 8 menunjukkan bahwa perlakuan BP4 menunjukkan hasil keasaman tanah $(\mathrm{pH})$ nilai rata-rata tertinggi yaitu 6,70 dan $\mathrm{K} 0$ menunjukkan hasil rata-rata kemasaman tanah terendah yaitu 6,12 . Berdasarkan uji lanjutan BNJ pada taraf 0,05\% memberikan hasil bahwa perlakuan BP4 berbeda nyata dengan semua perlakuan.

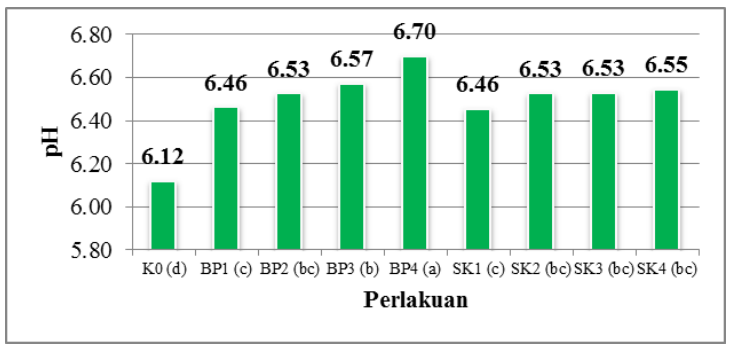

Gambar 8. Grafik rata-rata $\mathrm{pH}$ tanah pada setiap perlakuan (perlakuan yang diikuti oleh huruf-huruf yang sama (a,b,c,d,e,f) berarti tidak berbeda nyata pada uji taraf BNJ $0,05 \%$ serta menggunakan nilai pembanding BNJ 0,10).

\section{Kapasitas Tukar Kation (cmol/kg)}

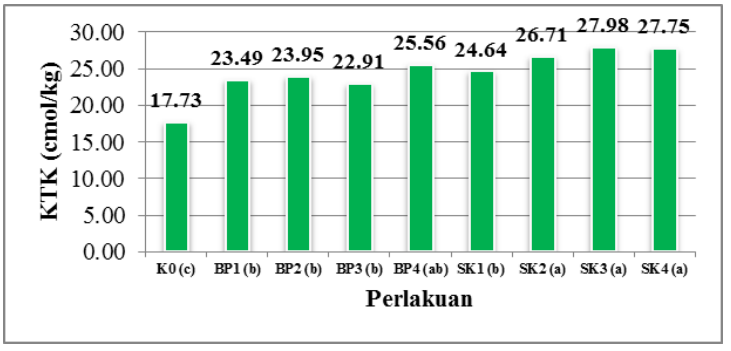

Gambar 9. Grafik rata-rata KTK pada setiap perlakuan (perlakuan yang diikuti oleh huruf-huruf yang sama (a,b,c,d,e,f) berarti tidak berbeda nyata pada uji taraf BNJ $0,05 \%$ serta menggunakan nilai pembanding BNJ 1,81).

Analisis sidik ragam menunjukkan bahwa perlakuan SK3 memberikan pengaruh sangat nyata terhadap KTK tanah. Gambar 9 menunjukkan bahwa perlakuan SK3 menunjukkan hasil KTK nilai rata-rata tertinggi yaitu $27,98 \mathrm{cmol} / \mathrm{kg}$ dan $\mathrm{K} 0$ menunjukkan hasil rata-rata KTK terendah yaitu $17,73 \mathrm{cmol} / \mathrm{kg}$. Berdasarkan uji lanjutan BNJ pada taraf $0,05 \%$ memberikan hasil bahwa perlakuan SK3 berbeda nyata dengan K0, BP1,BP2, BP3 dan SK1 serta 
memiliki pengaruh yang sama dengan BP4, SK2 dan SK4.

\section{Ca-dd (cmol/kg)}

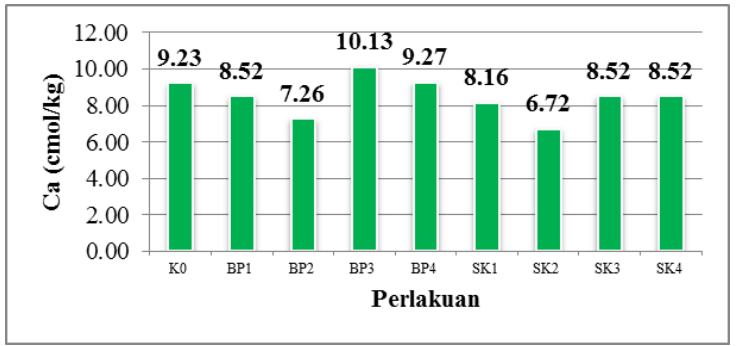

Gambar 10. Grafik rata-rata Ca-dd setiap perlakuan (perlakuan yang diikuti oleh huruf-huruf yang sama $(a, b, c, d, e, f)$ berarti tidak berbeda nyata pada uji taraf BNJ 0,05\% serta menggunakan nilai pembanding BNJ 2,56).

Analisis sidik ragam menunjukkan bahwa perlakuan SK3 memberikan pengaruh tidak nyata terhadap Ca-dd. Gambar 10 menunjukkan bahwa perlakuan BP3 menunjukkan hasil Ca-dd nilai rata-rata tertinggi yaitu $10,13 \mathrm{cmol} / \mathrm{kg}$ dan SK2 menunjukkan hasil rata-rata $\mathrm{Ca}$-dd terendah yaitu $6,72 \mathrm{cmol} / \mathrm{kg}$.

\section{Mg-dd (cmol/kg)}

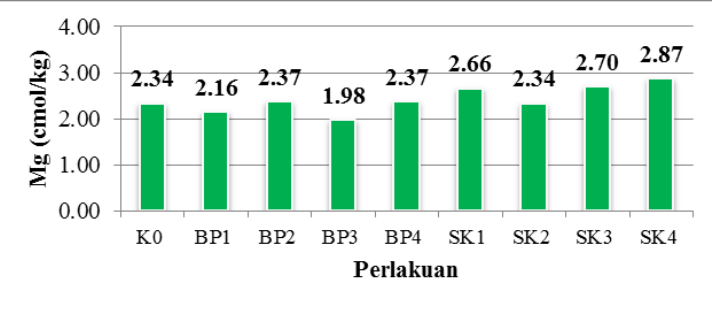

Gambar 11. Grafik rata-rata $\mathrm{Mg}$-dd pada setiap perlakuan (perlakuan yang diikuti oleh huruf-huruf yang sama $(a, b, c, d, e, f)$ berarti tidak berbeda nyata pada uji taraf BNJ $0,05 \%$ serta menggunakan nilai pembanding BNJ 0,92).

Analisis sidik ragam menunjukkan bahwa perlakuan SK1 memberikan pengaruh tidak nyata terhadap Mg-dd.. Gambar 11 menunjukkan bahwa perlakuan SK4 menunjukkan hasil $\mathrm{Mg}$-dd nilai rata-rata tertinggi yaitu $2,87 \mathrm{cmol} / \mathrm{kg}$ dan $\mathrm{BP} 3$ menunjukkan hasil rata-rata $\mathrm{Mg}$-dd terendah yaitu $1,98 \mathrm{cmol} / \mathrm{kg}$.

\section{Na-dd $(\mathrm{cmol} / \mathrm{kg})$}

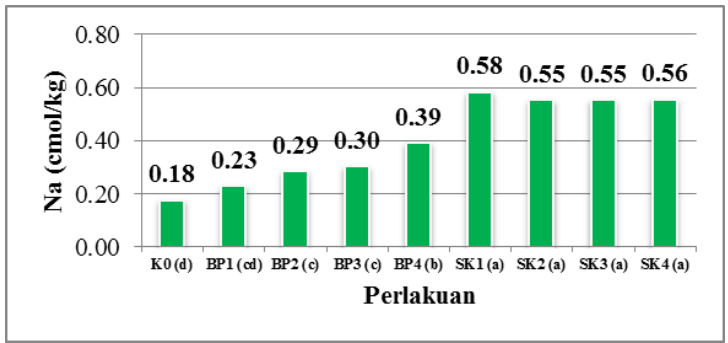

Gambar 12. Grafik rata-rata Na-dd pada setiap perlakuan (perlakuan yang diikuti oleh huruf-huruf yang sama (a,b,c,d,e,f) berarti tidak berbeda nyata pada uji taraf BNJ $0,05 \%$ serta menggunakan nilai pembanding BNJ 0,08).

Analisis sidik ragam menunjukkan bahwa perlakuan SK1 memberikan pengaruh sangat nyata terhadap Na-dd. Gambar 12 menunjukkan bahwa perlakuan SK1 menunjukkan hasil Na-dd nilai rata-rata tertinggi yaitu $0,58 \mathrm{cmol} / \mathrm{kg}$ dan $\mathrm{K} 0$ menunjukkan hasil rata-rata $\mathrm{Na}$-dd terendah yaitu $0,18 \mathrm{cmol} / \mathrm{kg}$. Berdasarkan uji lanjutan BNJ pada taraf $0,05 \%$ memberikan hasil bahwa perlakuan SK1 berbeda nyata dengan K0, BP1, BP2, BP3 dan BP4 serta tidak terlalu berbeda dengan SK2, SK3 dan SK4.

\section{K tersedia $(\mathrm{cmol} / \mathrm{kg})$}

Analisis sidik ragam menunjukkan bahwa perlakuan SK2 memberikan pengaruh tidak nyata terhadap K-tersedia. Gambar 13 menunjukkan bahwa perlakuan SK2 menunjukkan hasil $\mathrm{K}$-tersedia nilai rata-rata tertinggi yaitu $0,63 \mathrm{cmol} / \mathrm{kg}$ dan $\mathrm{K} 0$ menunjukkan hasil rata-rata K-tersedia terendah yaitu $0,31 \mathrm{cmol} / \mathrm{kg}$. 


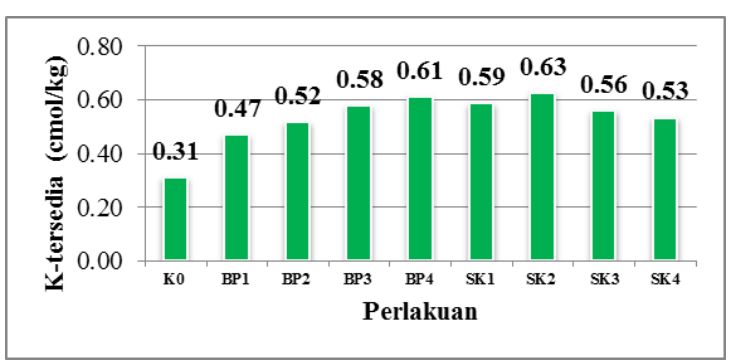

Gambar 13. Grafik rata-rata K-tersedia pada setiap perlakuan (perlakuan yang diikuti oleh huruf-huruf yang sama (a,b,c,d,e,f) berarti tidak berbeda nyata pada uji taraf BNJ $0,05 \%$ serta menggunakan nilai pembanding BNJ 0,14).

\section{Kadar K Tanaman (\%)}

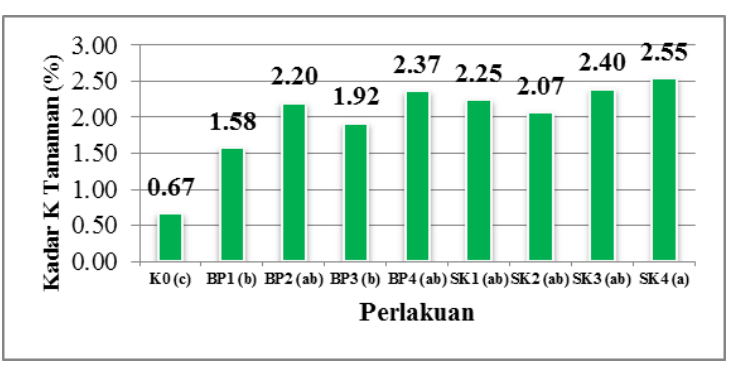

Gambar 14. Grafik rata-rata $\mathrm{K}$ dalam jaringan tanaman pada setiap perlakuan (perlakuan yang diikuti oleh huruf-huruf yang sama (a,b,c,d,e,f) berarti tidak berbeda nyata pada uji taraf BNJ 0,5\% serta menggunakan nilai pembanding BNJ 0,59).

Analisis sidik ragam menunjukkan bahwa perlakuan SK4 memberikan pengaruh nyata terhadap kadar $\mathrm{K}$ dalam jaringan tanaman. Gambar 14 menunjukkan bahwa perlakuan SK4 menunjukkan kadar K dalam jaringan tanaman nilai rata-rata tertinggi yaitu 2,55 \% dan $\mathrm{K} 0$ menunjukkan hasil ratarata $\mathrm{K}$ dalam jaringan tanaman terendah yaitu 0,67 \%. Berdasarkan uji lanjutan BNJ pada taraf $0,05 \%$ memberikan hasil bahwa perlakuan SK24 berbeda nyata dengan K0, BP1 dan BP3 serta tidak berbeda nyata dengan BP2, BP4, SK1, SK2, SK3 dan SK4.

\section{Pembahasan}

\section{Pengaruh Perlakuan terhadap Pertumbuhan Tanaman Jagung}

Pengaruh perlakuan terhadap tanaman jagung ditunjukkan berdasarkan tinggi tanaman, jumlah daun, berat segar dan berat kering. Berdasarkan parameter tersebut, perlakuan SK3 menunjukkan hasil terbaik dari keseluruhan perlakuan. Perlakuan SK3 (150 ml/pot), hasil tersebut dipengaruhi oleh perlakuan pupuk organik cair yang diaplikasikan ke tanaman jagung. Pemberian pupuk sangat mempengaruhi pertumbuhan tanaman jagung pada fase vegetatif. Unsur hara $\mathrm{N}, \mathrm{P}$ dan $\mathrm{K}$ yang tersedia dalam jumlah yang optimal dan seimbang akan mampu memberikan keseimbangan hara makro bagi tanaman. Menurut Sari (2015), di dalam sabut kelapa terkandung unsur hara dari alam yang sangat dibutuhkan tanaman yaitu kalium (K), selain itu juga terdapat kandungan unsur-unsur lain seperti kalsium $(\mathrm{Ca})$, magnesium $(\mathrm{Mg})$, natrium $(\mathrm{Na})$ dan fosfor (P). Apabila dilakukan proses perendaman sabut kelapa, kalium dalam sabut tersebut dapat larut dalam air sehingga menghasilkan air rendaman yang mengandung unsur K. Air hasil rendaman yang mengandung unsur $\mathrm{K}$ tersebut sangat baik jika diaplikasikan sebagai pupuk. Berdasarkan uji lanjutan, perlakuan SK3 memiliki pengaruh yang tidak berbeda nyata dengan SK4. Selain pertumbuhan tanaman jagung dipengaruhi oleh unsur $\mathrm{K}$ dalam sabut kelapa, namun juga dipengaruhi atas kecukupan unsur hara yang dapat diserap tanaman. Perlakuan antara sabut kelapa dan batang pisang menunjukkan perbedaan yang sangat signifikan, secara garis besar perlakuan sabut kelapa pada dosis (150-200 $\mathrm{ml} /$ pot) berkorelasi positif terhadap pertumbuhan tanaman jagung. Hal ini disebabkan karena perbedaan dosis dan ketersediaan unsur hara pada batang pisang dan sabut kelapa.

Berdasarkan parameter jumlah daun, perlakuan SK3 (150 ml/pot) memberikan pengaruh nyata. Penggunaan pupuk organik dalam bentuk cair memberikan pengaruh 
yang lebih efektif terhadap pertumbuhan tanaman sebab tanaman dengan mudah menyerap unsur hara. Menurut Sunarjono (1972), dengan memberikan pupuk organik ke dalam tanah, sistem perakaran tanah dapat berkembang lebih sempurna, penyerapan unsur hara semakin besar, akibatnya pertumbuhan tanaman semakin baik. Hal tersebut juga sesuai dengan pendapat Alfon et al (1993), kebutuhan K pada tanaman jagung berubah sesuai dengan kebutuhan dari proses-proses yang membutuhkan $\mathrm{K}$, seperti proses fotosintesis dan fiksasi $\mathrm{CO}_{2}$, transfer fotosintat ke berbagai pengguna serta hubungan dengan air dalam tanaman. Pemupukan $\mathrm{K}$ disamping pupuk $\mathrm{N}$ dan $\mathrm{P}$ secara berimbang pada jagung, membuat pertumbuhan pada tanaman menjadi lebih baik, tahan kerebahan, tahan terhadap hama dan penyakit serta kualitasnya dapat meningkat. Berdasarkan uji lanjutan, perlakuan SK3 berbeda nyata dengan K0, BP3 dan SK2 serta tidak berbeda nyata dengan BP1, BP2, BP4, SK1 dan SK4. Hal ini berarti perlakuan SK3 memberikan pengaruh yang lebih efektif pada parameter jumlah daun.

Ditinjau dari parameter pertumbuhan tanaman lainnya, yaitu berat segar/kering tanaman dan akar. Berat segar menunjukkan massa tanaman/akar dan jumlah air yang diserap oleh tanaman sedangkan berat kering menujukkan massa tanaman/akar sesungguhnya sebagai hasil dari proses fotosintesis. Perlakuan yang memberikan pengaruh terbaik terhadap berat segar dan berat kering akar maupun tanaman adalah perlakuan SK3 (150 ml/pot). Perlakuan ini menunjukkan hasil terbaik karena didalam POC sabut kelapa terdapat unsur hara makro dan mikro. Interaksi yang nyata ini dipengaruhi oleh bentuk pupuk cair yang merupakan larutan yang dapat mempercepat reaksi dan ketersediaan hara $\mathrm{K}$ dalam tanah. Hal ini sesuai dengan pendapat Novizan (2005) yang menyatakan bahwa penambahan bahan organik selain meningkatkan jumlah hara makro dan mikro juga dapat meningkatkan kapasitas tukar kation tanah yang akhirnya akan berpengaruh positif untuk pertumbuhan tanaman. Seperti yang dikutip pula oleh Harjadi (2002) dalam Syahriani (2014), yang menyatakan bahwa unsur hara yang tersedia dalam jumlah yang cukup untuk pertumbuhan tanaman menyebabkan proses pemanjangan sel berlangsung cepat sehingga mengakibatkan pertumbuhan batang, daun, akar pada tanaman berlangsung cepat. Kelebihan pupuk cair organik diantaranya dapat secara cepat mangatasi defesiensi hara dan mampu menyediakan hara secara cepat, pupuk organik cair umumnya tidak merusak tanah dan tanaman, pupuk cair mengandung bahan pengikat sehingga larutan pupuk yang diberikan ke permukaan tanah bisa langsung digunakan oleh tanaman, menggemburkan tanah, meningkatkan pengikatan antar partikel, meningkatkan kapasitas tukar kation (KTK), meningkatkan ketersediaan unsur hara, meningkatkan proses pelapukkan bahan mineral (Nugroho, 2013).

\section{Pengaruh Perlakuan terhadap Tanah}

Berdasarkan hasil analisis yang dilakukan di laboratorium, diperoleh kandungan unsur kimia tanah berbeda pada masing perlakuan. Terdapat perbedaan yang signifikan antara perlakuan kontrol (K0) dan perlakuan lainnya, dari hasil uji lanjutan perlakuan menunjukkan SK3 berpengaruh nyata terhadap pertumbuhan tanaman jagung, Nadd dan KTK namun berpengaruh tidak nyata terhadap $\mathrm{pH}$ tanah. SK2 (100ml/pot) menunjukkan nilai rata-rata tertinggi yaitu $0,63 \mathrm{cmol} / \mathrm{kg}$ terhadap peningkatan $\mathrm{K}$ dalam tanah dan berpengaruh nyata terhadap KTK, pada dosis $(200 \mathrm{ml} /$ pot $)$ berpengaruh nyata terhadap c-organik, KTK dan kadar K dalam tanaman dan sabut kelapa pada dosis $(150 \mathrm{ml} / \mathrm{pot})$ berpengaruh nyata terhadap tinggi tanaman, jumlah daun, berat kering tanaman, berat kering akar dan KTK, namun berpengaruh tidak nyata terhadap $\mathrm{pH}$ tanah. Menandakan bahwa sabut kelapa mengandung unsur hara kalium yang lebih besar dan pupuk organik cair mampu menyediakan unsur hara secara cepat. Hal ini sesuai dengan pendapat Mutryarny et al (2014), berbagai mikroorganisme yang 
terdapat dalam pupuk organik cair dari sabut kelapa ikut bekerja di dalam tanah sehingga dapat memperbaiki sifat fisik, kimia dan biologi tanah. Pada pupuk organik cair dari sabut kelapa unsur hara yang tertinggi adalah kalium $(\mathrm{K})$.

Ditinjau hasil uji lanjutan dari nilai kemasaman tanah, perlakuan terbaik terdapat pada tanah dengan perlakuan BP4 pupuk organik cair batang pisang $(100 \mathrm{ml} / \mathrm{pot})$ yang menunjukkan hasil $\mathrm{pH}$ tertinggi, yaitu 6,70 . Berdasarkan kriteria penilaian sifat kimia tanah oleh staf pusat penelitian tanah (1983), tergolong netral (Hardjowigeno, 2003). Terjadi peningkatan $\mathrm{pH}$ tanah sebelum dan sesudah pemupukan dari tanah tergolong agak masam $(6,08)$ hingga menjadi netral $(6,70)$, hal ini disebabkan karena penggunaan pupuk organik dapat menambah jumlah senyawa-senyawa organik dalam tanah yang dapat mengikat $\mathrm{H}$ dan $\mathrm{Al}$ sebagai penyebab kemasaman tanah. $\mathrm{pH}$ tanah meningkat pada perlakuan batang pisang yang dapat menstabilkan $\mathrm{pH}$ tanah dibandingkan dengan POC sabut kelapa, karena sabut kelapa memiliki $\mathrm{pH}$ cenderung masam.

Pemberian perlakuan pupuk organik akan meningkatkan kandungan $\mathrm{C}$-organik dalam tanah. Hal ini terjadi karena pupuk organik merupakan salah satu sumber karbon untuk tanah. Perlakuan SK4 (200ml/pot) yang paling efektif meningkatkan kandungan C-organik sebesar $(2,47 \%)$. Peningkatan c-organik tergolong dari rendah sampai sedang-tinggi (staf pusat penelitian tanah, 1983 dalam Hardjowigeno 2003). Sabut kelapa mengandung unsur $\mathrm{C}$ sebagai bahan karbon (Pertiwi dan Herumurti, 2009).

Kapasitas Tukar Kation (KTK) pada tanah setelah perlakuan mengalami peningkatan dari rendah menjadi sedangtinggi. Nilai KTK tertinggi ditunjukkan pada perlakuan SK3 (150 ml/pot) telah uji lanjutan BNJ pada taraf $0,05 \%$ memberikan hasil bahwa perlakuan SK3 berbeda nyata dengan K0, BP1,BP2, BP3 dan SK1 serta memiliki pengaruh yang sama dengan BP4, SK2 dan SK4. Hal ini disebabkan adanya korelasi positif antara meningkatnya pertukaran basa-basa kation dan $\mathrm{pH}$ tanah. Menurut Pairunan et al (1999), kapasitas tukar kation tanah yang memiliki banyak muatan tergantung dengan perubahan $\mathrm{pH}$. Keadaan tanah yang masam menyebabkan tanah kehilangan kapasitas tukar kation dan kemampuan menyimpan hara kation dalam bentuk dapat ditukar, karena perkembangan muatan positif. Hal ini berarti pada perlakuan SK3, kapasitas tukar kation mengalami peningkatan seiring dengan meningkatnya $\mathrm{pH}$ tanah. Selain korelasi positif $\mathrm{pH}$ dan kapasitas tukar kation, C-Organik juga berkorelasi positif terhadap potensi peningkatan kapasitas tukar kation. Nilai kapasitas tukar kation tanah pada umumnya berkisar antara $25-45 \mathrm{cmol} / \mathrm{kg}$ sampai dengan kedalaman 1 meter. Hal didukung oleh Rosmarkam et al (2002), pengaruh bahan organik tidak dapat disangkal terhadap kesuburan tanah. Telah dikemukakan bahwa bahan organik mempunyai daya jerap kation yang lebih besar daripada koloid liat. Berarti semakin tinggi kandungan bahan organik suatu tanah makin tinggi pula lah KTK-nya.

Terdapat pula peningkatan kandungan hara $\mathrm{K}$-tersedia setelah diberikan perlakuan, secara keseluruhan perlakuan menunjukkan adanya peningkatan ketersediaan K-tersedia ditandai dengan adanya perbedaan nilai antara $\mathrm{K} 0$ dan semua perlakuan. Peningkatan K-tersedia tertinggi ditunjukkan pada perlakuan SK2 (100 $\mathrm{ml} / \mathrm{pot}$ ) yaitu $0,63 \mathrm{cmol} / \mathrm{kg}$. Berdasarkan kriteria penilaian sifat kimia tanah oleh staf pusat penelitian tanah (1983), nilai Ktersedia sebelum perlakuan tergolong rendah. Kandungan unsur hara K-tersedia pada tanah sebelum dan sesudah perlakuan mengalami peningkatan kandungan dari rendah ke tinggi. Hal ini disebabkan karena kalium pada sabut kelapa lebih besar dan ditunjang oleh sifat pupuk organik cair yang memungkinkan adanya mikroorganisme, mikroorganisme sebagai katalisator, dengan kehadiran bakteri dan aktivitasnya akan sangat berpengaruh terhadap peningkatan kandungan kalium. Kalium dapat diikat dan disimpan dalam sel oleh bakteri dan jamur (Hidayati et al, 2011). 


\section{Pengaruh Perlakuan terhadap Kadar K dalam Tanaman}

Berdasarkan uji lanjutan menunjukkan bahwa perlakuan SK4 (200ml/pot) menunjukkan hasil $\mathrm{K}$ dalam jaringan tanaman nilai rata-rata tertinggi yaitu $2,55 \%$ namun tidak berbeda nyata dengan SK3 $(150 \mathrm{ml} /$ pot $)$ yaitu $2,40 \%$ serta K0 menunjukkan hasil rata-rata $\mathrm{K}$ dalam jaringan tanaman terendah yaitu $0,67 \%$. Berdasarkan hasil yang diperoleh dapat diketahui bahwa dengan semakin bertambahnya dosis pupuk cair yang diberikan maka kelarutan dan kadar hara dalam tanaman juga semakin meningkat. Hal ini berkorelasi dengan meningkatnya ketersediaan $\mathrm{K}$ di tanah dengan pemberian pupuk organik cair. Selain itu, kandungan K pada pupuk organik cair sabut kelapa yang dihasilkan dari analisis pupuk adalah $(2.48 \%)$, sehingga dengan melakukan beberapa kali pemupukan mampu mensuplai hara $\mathrm{K}$ untuk tanaman. Hal ini sesuai dengan pernyataan Djalil (2003), semakin tinggi konsentrasi kalium di tanah maka semakin tinggi kadar $\mathrm{K}$ dalam tanaman.

\section{KESIMPULAN}

1. Perlakuan pupuk organik cair sabut kelapa pada dosis 100ml/pot menunjukkan nilai rata-rata tertinggi yaitu $0,63 \quad \mathrm{cmol} / \mathrm{kg} \quad$ terhadap peningkatan $\mathrm{K}$ dalam tanah dan berpengaruh nyata terhadap KTK.

2. Perlakuan pupuk organik cair sabut kelapa pada dosis 200ml/pot berpengaruh nyata terhadap c-organik, KTK dan kadar K dalam tanaman.

3. Perlakuan pupuk organik cair sabut kelapa pada dosis $150 \mathrm{ml} /$ pot berpengaruh nyata terhadap tinggi tanaman, jumlah daun, berat kering tanaman, berat kering akar dan KTK, namun berpengaruh tidak nyata terhadap $\mathrm{pH}$ tanah.

\section{DAFTAR PUSTAKA}

Agbaje G. O. and Akinlosotu T. A. 2004. Influence of NPK fertilizer on tuber yield of early and late-planted cassava in a forest alfisol of southwestern Nigeria.African: African Journal of Biotechnology 3 (10): 547-551.

Ahmad, A., 2011. Meningkatkan Pelepasan Unsur Hara dari Batuan Beku dengan Senyawa Humat (Doctoral dissertation, Tesis (tidak diterbitkan). Bogor: institute pertanian Bogor).

Alfon, J. B. dan Aryantoro. 1993. Populasi dan Pemupukan $\mathrm{N}$ dan $\mathrm{K}$ Tanaman Jagung Varietas TC 1 di Seram Maluku. Jurnal Agribisnis dan Perikanan. 8(1):85-89.

Djalil, M. 2003. Pengaruh Pemberian Pupuk $\mathrm{KCl}$ Terhadap Pertumbuhan dan Pembentukan Komponen Tongkol Jagung Hibrida Pioneer-23. Padang: Fakultas Pertanian Universitas Andalas.

Hardjowigeno, S. 2003. Klasifikasi Tanah dan Pedogenesis. Jakarta (ID): Akademika Pressindo.

Hidayati, Y.A., Kurnani, A., Marlina, E.T., Harlia, E. (2011). Kualitas pupuk cair hasil pengolahan fases sapi potong menggunakan Saccharomyces cereviceae. Jurnal Ilmu Ternak 11(2): 104- 107.

Lingga, P. dan Marsono. 2003. Petunjuk penggunaan pupuk. Jakarta: Penerbit Swadaya-150 hal.

Mengel, K. and E. A. Kirkby. 1982. Principles of plant nutrition. Switzerland: International Potash Institute Bern.

Mutryarny et al. 2014. Pemanfaatan Urine Kelinci untuk Meningkatkan Pertumbuahan dan Produksi Tanaman Sawi Caisim (Brassica juncea L.) Verietas Tosakan. Jurnal Ilmiah Pertanian Vol.11 No.2 Februari 2014. 
Mutscher, H. 1995. Measurement and assessment of soil potassium. IPI Research Topics No. 4, pp. 102. Switzerland: International Potash Institute Basel.

Novizan. 2005. Petunjuk Pemupukan yang Efektif. Jakarta: Agro Media Pustaka.

Nugroho, P. 2013. Panduan Membuat Pupuk Kompos Cair. Yogyakarta: Pustaka Baru Press.

Pairunan, Anna K., J. L. Nanere, Arifin, Solo S. R. Samosir, Romualdus Tangkaisari, J. R. Lalopua, Bachrul Ibrahim, Hariadji Asmadi, 1999. Dasar-Dasar Ilmu Tanah. Makassar: Badan Kerjasama Perguruan Tinggi Negeri Indonesia Timur.

Pertiwi, D., dan Herumurti, W., 2009. "Study Pemanfaatan Sabut Kelapa Sebagai Karbon Aktif Untuk Menurunkan Konsentrasi Fenol“". Tugas Akhir. Jurusan teknik Lingkungan FTSP-ITS. Surabaya.

Prawoso. 2001. Kandungan Unsur Hara dalam Sabut Kelapa. Diakses dari http://books.google.co.id/books tanggal 30 januari 2019 pukul 15.06 WITA

Pusat Penelitian Tanah, 1983. Kriteria Penilaian Data Sifat Analisis Kimia Tanah. Bogor: Balai Penelitian dan Pengembangan Pertanian Departemen Pertanian.

Rahmasari, V. 2008. Pemanfaatan air abu sabut kelapa dalam pembuatan agar agar kertas dari rumput laut. Bogor: Skripsi sarjana Institut Pertanian Bogor.

Rosmankam, A., dan Yuwono, N.W. 2002. Ilmu Kesuburan Tanah. Yogyakarta (ID): Kanisius.

Sari, S.Y. 2015. Pengaruh Volume Pupuk Organik Cair Berbahan Dasar Serabut Kelapa (Cocos nucifera) Terhadap
Pertumbuhan dan Hasil Panen Sawi Hijau (Brassica juncea). Skripsi.

Satuhu, S. dan Supriyadi, A. 1999. "Pisang" Budidaya, Pengolahan dan Prospek Pasar. Jakarta: Penebar Swadaya.

Sheldrick, W.F. 1985. World Potassium Reserves. Pp. 3-28. In R.D. Munson (Ed.). Wisconsin, USA: Potassium in Agriculture. Am. Soc. Agron.

Sugiarti, H. 2011. Pengaruh Pemberian Kompos Batang Pisang Terhadap pertumbuhan Semai Jabon (Anthophalus cadamba Mig.). Bogor: Skripsi pada Departemen Silvikultur Fakultas Kehutanan IPB.

Sunarjono, H. 1972. Kunci Bercocok Tanam Sayuran Penting di Indonesia. Jakarta: Lembaga Penelitian Hortikultura.

Syahriani. 2014. Perbaikan Kualitas Lahan Kering melalui Pertanian Terpadu Rambutan, Jagung, dan Gamal di Kabupaten Gowa (Skripsi). Makassar: Universitas Hasanuddin. 